\title{
Cheravirus and Sadwavirus: two unassigned genera of plant positive-sense single-stranded RNA viruses formerly considered atypical members of the genus Nepovirus (family Comoviridae)
}

O. Le Gall · Hélène Sanfaçon · M. Ikegami ·

T. Iwanami - T. Jones · A. Karasev •

K. Lehto $\cdot$ J. Wellink $\cdot$ T. Wetzel $\cdot$ N. Yoshikawa

Published online: 29 April 2009

(C) Springer-Verlag 2009

Erratum to: Arch Virol (2007) 152:1767-1774

DOI 10.1007/s00705-007-1015-0

In the published original version of this article, Table 1, last line:

- black raspberry necrosis virus (BRNV), the sequence accession number for RNA-1 is not given correct.

The correct sequence accession number should read: NC_008182.
The online version of the original article can be found under doi:10.1007/s00705-007-1015-0.

\section{O. Le Gall}

INRA Bordeaux-Aquitaine and Université Victor Segalen,

Villenave d'Ornon, France

\section{H. Sanfaçon $(\bowtie)$}

Pacific Agri-Food Research Centre,

Agriculture and Agri-Food Canada, P.O. Box 5000,

4200 Highway 97, Summerland, BC V0H-1Z0, Canada

e-mail: sanfaconh@agr.gc.ca

M. Ikegami

Graduate School of Agricultural Science, Tohoku University,

Sendai, Japan

\section{T. Iwanami}

National Institute of Fruit Tree Science, Tsukuba, Japan

T. Jones

Scottish Crop Research Institute, Dundee, Scotland, UK

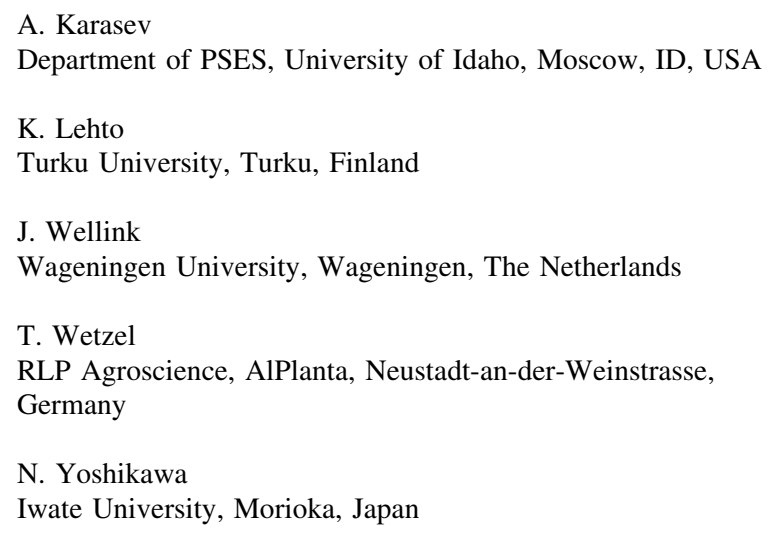

